\title{
Explaining Expansion of Persian Empire: The Use of Cavalry
}

\author{
Junjie Huang ${ }^{1, \dagger}$, , Zhengyi $\operatorname{Lin}^{2, \dagger}$, Bolong Wang ${ }^{3, \dagger, *}$ \\ ${ }^{1}$ Sendelta International Academy, Shenzhen, 518006, China \\ ${ }^{2}$ Keji High School, Xiamen, 361005, China \\ ${ }^{3}$ Haidian Foreign Language Academy, Beijing,100097, China \\ *Corresponding author. Email: guanghua.ren@gecacademy.cn
}

These authors contributed equally.

\begin{abstract}
The essay is to explore why the expansion of the Persian empire was so successful in 6th B.C. This phenomenon has been observed in the 6th B.C., and the territory of the Persian empire crossed the Asian, African, and European continent. The essay uses the case study method. It focuses only on the Persian empire, but it will look into this case from a comparative perspective with the old Chinese empire and the Roman empire. Through the document analysis, the essay presents a historical interpretation of the expansion of the Persian empire. The result of the essay reveals one of the most important reasons for its successful expansion is the use of cavalry. In conclusion, the essay deepens our understanding of the Persian empire. Moreover, the essay can be useful to reveal the historical root of contemporary disorder in the Middle East. Therefore, it might be helpful to propose solutions for the peace of the region. Admittedly, the essay is limited because it only focuses on the military perspective but does not look at other economic and cultural aspects. Further studies can look into more parts of the economic and cultural aspects of the Persian empire.
\end{abstract}

Keywords: Persian empire, expansion, cavalry, 6thB.C.

\section{INTRODUCTION}

The essay's research question is why cavalry is important to the expansion of the Persian empire. This research question is puzzling because there is a diverse community of ethnic groups, but only the Persian empire managed to expand and finally become a great empire.

The essay question is located in the research topic of the study of the Persian empire and military study. To give background information, among diverse ethnic groups in the region, the Persian ethnic group was relatively weak at the beginning. However, through a series of expansion and conquest, in the 6th B.C., finally, the Persians became a great empire that crossed the Asian, African, and European continent.

This essay will focus on the Persian empire. To give background information, among diverse ethnic groups in the region, the Persian ethnic group was relatively weak at the beginning. However, through a series of expansion and conquest, in the 6th B.C., finally, the Persians became a great empire that crossed the Asian, African, and European continent. This is a unique case because its military approach is distinct from that of the Chinese and Roman empires. Nevertheless, this case applies to the Chinese and Roman empires due to the share of similarity.

This topic matters because the essay deepens our understanding of the Persian empire. It can help to reveal the historical root of contemporary disorder in the Middle East. Therefore, it might be helpful to propose solutions for the peace of the region.

The essay is divided into several sections. After the introduction, section I will first present the historical development of the Persian empire regarding its territorial expansion. Then, section II will explain this phenomenon from the aspect of cavalry. After that, section III will compare this with the Chinese empire. Next, section IV will compare it with the Roman empire. The final conclusion will reflect on the limitation of the essay and sheds light on further study. 


\section{HISTORY BACKGROUND}

The Persian empire was relatively weak initially, but it became powerful after its expansions. It was mainly under Turans and Elamites' conquest separately at first. Then their conquest combined, forming an Iranian group. Many countries --Medes and Assyrians--were established there. Cyrus, the king of Persia, combined Persian and Median, establishing a powerful military in 550 B.C.E. He also made expansions in the Middle East. It took him twenty years to establish such a great Empire. Cyrus started expanding from Anatolia, the Kingdom of Lydia, and Greece; Cyrus the Great respected the customs and religions of the lands he conquered. Brooks says the way Cyrus treated the Greeks made him highly esteemed among them, which reduced the possibility of the Greek revolts." [1]

Moreover, other groups conquered by him were also treated the same as the Greeks. This made the unify of the Persian empire possible by gaining the reputation of residents. Lydian and Mesopotamian regions were conquered after the Greek's conquest, which was a peaceful expansion.

After that was the conquest of Babylon: The king of Babylon at that time was like a tyrant. Thus people considered the conquest of Cyrus as a save. So the Persian troops entered Babylon without any resistance. The way that Cyrus conquered caused several positive consequences overall. Since Babylon conquered the Jewish people, Cyrus' conquest of Babylon freed the Jewish people due in $539 \mathrm{BCE}$, which they were saved from being imprisoned. Therefore, Cyrus was seen as the 'messiah' (the savior) of the Jewish people.

On the one hand, the people he conquered respected him well. Thus few of them revolted against him. On the other hand, he focused on selecting royal ministers, which may enhance his reign. He conquered central Asia in today's Afghanistan, conquering all known worlds, having brought into subjection every nation without exception

Eventually, he died in the fight with Scythans. According to crystalinks, Superimposed on modern borders, the Achaemenid Empire under Cyrus's rule extended approximately from Turkey, Israel, Georgia, and Arabia in the west to Kazakhstan, Kyrgyzstan, the Indus River (Pakistan), and Oman in the east [2]. Cyrus the Great's dominions comprised the largest empire the world had ever seen. At the end of Cyrus's rule, the Achaemenid Empire stretched from Asia Minor in the west to the northwestern areas of India in the east.

After Cyrus, Cambyses II, the son of Cyrus, conquered both the eastern coast of the Mediterranean and Egypt. As a result, at that time, the Persian empire became the biggest empire in the world in $522 \mathrm{BCE}$ (even bigger than the China empire in Zhou Dynasty). Darius, the third king of the Persian empire, succeeded Cambyses II's position and established a government that became a model for much future government. He extended the borders of the empire into India and Europe. He also fought two wars with the Greeks, which were disastrous. In conclusion, Darius held the empire at its peak, then including the entire Middle East, the Caucasus, Central Asia, parts of the Balkans (Bulgaria-Romania-Panonia), portions of north and northeast Africa including Egypt (Mudraya), eastern Libya, coastal Sudan, Eritrea), as well as northeast portions of and greater India (Pakistan and northwest India), the Aegean Islands and northern Greece/Thrace-Macedonia.

\section{THE UTILIZATION OF CAVALRY SYSTEM IN THE PERSIAN EMPIRE}

Cavalry played a very significant role in the military expansion of the Persian empire. In brief, the Persian cavalry had several outstanding advantages that contribute to its military expansion.

The first was that the horses of it had the highest quality. In the book of The Histories, Herodotus illustrated that "having heard that the horses of Thessaly were the best in Hellas, he had held a race there to test his horses against those of the Thessalians. The Greek horses were left far behind" [3]. This example supports that Persian horses were superior to other horses, which implies the strength of Persian cavalry, especially when battling with another cavalry in the same condition.

Additionally, the cavalry had extraordinary high mobility. In particular, this ability could be useful in protecting retreating infantry against hostile pursuits. To be specific, since cavalry had high mobility, it could bring up the rear to defend enemy pursuers and block them from allied troops. For instance, Herodotus, in his book, pointed out that "[cavalry] provided vital assistance to the fleeting troops by riding up close to the Hellenes and blocking them from the fleeting allies" [4]. Also, high mobility could cause severe losses on disorder enemies. In The histories, Herodotus described that "when the Megarians and Phleiasians drew near their enemies, the Theban horsemen caught sight of them rushing ahead in disorder, and charged them on horseback". This mobility of cavalry could be a decisive blow for enemies at the edge of collapse, so it could crush the last straw of the enemy and win a decisive victory. Moreover, sometimes it was employed to ride behind the enemy's army to capture or at least disrupt food and water supply. For instance, Herodotus narrated that "[the horsemen] also blocked and destroyed the spring of Gargaphia, which had been the source of water for the whole Greek army". Herodotus also mentioned that "there were, in fact, other problems that distressed them even more than these: they no longer had any food, since the auxiliaries they had sent to the Peloponnese to bring back provisions had been completely blocked by the 
enemy's cavalry and were unable to reach their camp". Compared to Greek heavy infantry, which moved more slowly and was less flexible, Persian cavalry indeed had its unique virtue.

Furthermore, Persian cavalry took advantage of its capacity to hurl missiles from a distance to attack enemies. In other words, it often attacks in-unit relays, using spears and bows, rather than closing immediately with an enemy. Once this harassment had broken the enemy's formation, the cavalry could pursue and ride down fleeting fugitives. For example, in Herodotus's book, he referred to "that was how he exhorted his troops. So when the cavalry that had surrounded them charged as though about to kill them, and the horsemen raised their weapons as though they were going to throw them, .......". $\mathrm{He}$ also mentioned that "the horsemen rode out and attacked, inflicting injuries on the entire Greek army with their javelins and arrows, for they were mounted archers. The Hellenes couldn't close with them". Thus those documents showed that how advantageous and effective the cavalry was if it could use the long-range weapon.

However, these tactics require open, level ground to work effectively. Maybe it is why Datis and Artaphrenes are said to have landed at Marathon and Mardonios in 479, leaving Attica for Boeotia. Here are some records from Herodotus' book. "Since the Hellenes refused to come down onto the plains, ......, the horsemen rode out against Hellenes and charged them by regiment, doing significant harm to them and insulting them as they did so by calling them "women". Now, just by chance, the Megarians happened to be deployed in the most vulnerable position of the entire battlefield, and it was they who receive the brunt of the cavalry's assaults". These records reflected that open and flat areas were more suitable for the cavalry, so Mardonios wanted to seduce the Greek army to the plain.

Another huge vantage can be credited for developing organized cavalry forces that were tactically used on the battlefield along with other mixed forces like Sparabara (archers with large shields) and Takabara (heavy peltasts). Seemingly inspired by the neighboring Sakas (many of whom were later used as mercenaries), some of the native Persians adopted formations of shielded cavalrymen who carried smaller, lighter versions of the spara (shield).

According to Mandal, the latter half of the 5th century $\mathrm{BC}$ also coincided with the rise of the shock cavalry that sort of mirrored the knightly class of Medieval Europe [5]. The rich Persian nobility usually furnished such heavily armored regiments (called the Persian Cuirassiers by Xenophon) in times of the disparate civil wars and clashes that frequently plagued the empire. And they were supposedly used on the battlefield as armored 'battering rams' that smashed through the enemy ranks in their column-like formations.
Admittedly, it was not enough to merely depend on the cavalry. It was also important to combine infantry and cavalry attacks for mutual support. Cyrus, the king of Persian, for instance, arrayed his army reasonably. Herodotus, in his book, described that "he brought together all the camels that had accompanied his army carrying food and equipment. He ordered them to advance in front of the cavalry of Croesus. Then he commanded the infantry to follow after the camels, and he placed his entire cavalry behind the infantry" [6]. This arrangement was so rational and tricky that it undermined Lydian cavalry forces and combined cavalry and infantry organically. So organized cavalry forces that were tactically used on the battlefield and other mixed forces like Sparabara (archers with large shields) and Takabara (heavy peltasts) were gradually developed. Seemingly inspired by the neighboring Sakas (many of whom were later used as mercenaries), some of the native Persians adopted formations of shielded cavalrymen who carried smaller, lighter versions of the spara (shield).

Intriguingly enough, the latter half of the 5th century $\mathrm{BC}$ also coincided with the rise of the shock cavalry that sort of mirrored the knightly class of Medieval Europe. The rich Persian nobility usually furnished such heavily armored regiments (called the Persian Cuirassiers by Xenophon) in times of the disparate civil wars and clashes that frequently plagued the empire. And they were supposedly used on the battlefield as armored 'battering rams' that smashed through the enemy ranks in their column-like formations.

However, Persian leadership in the Greek-Persian wars failed. An obvious example is the absence of cavalry forces from Herodotus' account of Marathon. Datis and Artaphrenes withdrew cavalry without considering possible aftermath, leaving their infantry vulnerable to a sudden Greek attack of this to withdraw. Also, at Plataea, Mardonios led both infantry and cavalry but could not keep his units in proper formation. All of these highlighted the importance of cavalry as a military force, especially in the ancient war.

\section{COMPARING CHINESE CAVALRY WITH PERSIAN CAVALRY}

Historical evidence indicates that horse was originally domesticated by nomadic tribes located in temperate grassland across Asia and Europe. In Botai, Kazakhstan, tons of horse bone was excavated, which archeologist surmised is the earliest domestication of horse [7]. As the Persian empire took advantage of cavalry in expansion, it then became a powerful group among the middle eastern empires. Nevertheless, ancient China has also developed the usage of cavalry in the military; it has contributed a lot to ancient Chinese warfare since it became a crucial part of the Chinese army in ancient times. 
In Chinese civilizations, cavalry was first massively used in a state named Zhao. Located in the Northern part of the Huabei plain, Zhao often got provoked and attacked by nomadic tribes in the northern steppe. Still, they cannot have an efficient confrontation between these tribes since chariots have less mobility. To avoid this situation, the duke of the state, Zhao, Wulingwang, introduced the cavalry system. Because of this action, Zhao's power grown exponentially. Later, this system spread across China. In the Qin dynasty, cavalry massively increased. The terra-cotta army of Shi Huang Di can support this claim.

In the Han dynasty, the nomadic group of Xiong $\mathrm{Nv}$ has become a major threat to the Chinese civilization. Therefore, scholars and intellectuals proposed to enhance the power of cavalry and replaced the cumbersome chariot [8]. Emperor Wen Di issued an act to support the army: civilians who domesticate horses would not need to finish the compulsory military service. It surely stimulates the development of cavalry. The 'reign of Wen Jing' has contributed a lot to the growth of national wealth, thus making armoring highly standardized weapons to the cavalries possible. However, differed from the Persian empire's expansion, the Han dynasty took cavalry uses for protection rather than expansion. Before the second war of the Hexi Corridor, Emperor $\mathrm{Wu}$ of the Han Dynasty ordered General Huo Qubing to lead his army attacking the Huns in the Hexi region for the second time, thus launching the Second Hexi War. General Huo Qubing and General Gongsun Ao took three thousand cavalries. They sent troops from the north and divided their armies to attack westward. General Huo Qubing led his cavalry attack forward, launching a fierce attack, which made the Huns unprepared to respond to the fight. After the war, the Han army won a decisive triumph; with 3000 cavalries, General Huo QuBing beat back the Huns thousands of miles from Mount Yanran. As for the strategic view, Huns used the individual cavalry system, which sacrifices the strength to exchange for its flexibility. At the same time, the Han dynasty took advantage of heavy cavalry, which possessed a more powerful attack than Huns' cavalry. Plus, the technique of smelting supports the military of the Han dynasty.

After the Jin dynasty, nomadic tribes from the north attacked the Chinese civilization and set up their own realms, which kept their cavalry traditions. Until the Ming dynasty, the Mongol empire was eliminated from the north. Cavalry started to decline due to the decrease in demand. Moreover, gunpowder was invented. It has a stronger power than arrow and cavalry, which indirectly caused the marginalization of cavalry. In the late 19th century, the Qing dynasty started industrialization, riffles started to massively produced in China. In the 1950s, PRC invested more money in tanks and airplanes, causing the decrease of cavalry in China. Cavalry was being flawed anyway. As we see from history, cavalry then evolved into more complicated forms that it was more adaptive to varied situations. From that, we could say, overall, calvary has been developed with time continuously.

Persian empire once became a prosperous civilization, which was well-known for its conquer of Mesopotamia, Anatolia, and Egypt. The Chinese civilization also influenced the world a lot. The cavalry system of these empires is one of the major reasons why it won these wars. Overall, the cavalry army in both nations is indefectible. There is some minor deviation between them. In Persian civilization, riding a horse is a symbol of nobility. Therefore, horses were required in many scenarios, no matter in daily life or on the battlefield.[1] As a result, horses were highly valued in their society, and nobles well protected them. This special protection may lead to the origin of Heavy cavalry. Heavy cavalry has advantages like having the strong ability to strike, high level of protection of horse and warriors. Still, it has its unique disadvantages: low mobility, high cost of maintaining and carrying, etc. On the contrary, the Chinese do not have heavy cavalry but relatively swift. Chinese cavalry got a huge influence on nomadic tribes in the northern part of China, which do not carries cumbersome weapons. Chinese warriors who ride the horse have abandoned the traditional Chinese custom, adopted the Hu cloth, which is more convenient. But, more than copy, Chinese warriors use the Metal arrow, broadsword, and spear, which is more powerful than bone weapons of nomadic people. However, during the Qin dynasty, the state of Qin took use of infantry to fight against Zhao, winning a triumph over Zhao's cavalry. Additionally, the Greeks beat Persians with infantry as well. These two cases showed the withdraws of cavalries: although cavalries were crucial for the military at that time, their weakness would be the low flexibility compared to infantry.

\section{CONTRASTING CAVALRY OF ROMAN EMPIRE WITH THAT OF PERSIAN EMPIRE}

Roman Empire was founded by Octavian, Caesar's adopted son, in $27 \mathrm{BC}$, and it lasted until 476. Roman Empire is a good case for comparison because it was the most powerful and strongest Empire in the West than the Persian Empire. In the Roman world, the cavalry did not always occupy the center of its military force.

For example, According to UNVI, Roman cavalry was not as important in the Roman thought process [9]. It was considered the second and weakest part of the Roman army. In addition, Bishop argues that Roman cavalry originated from Celtic heritage and gradually took a developmental life independently [10]. And the harness of Roman cavalry functions completely practical rather than decoration. 
However, Cartwright points out that cavalry could provide useful cover on the flanks of armies, could be a tactic use of disrupting enemy infantry formation, and could pursue enemies during retreating [11]. Therefore, the performance of cavalry determines the won or lost in the ancient battle. Besides, the cavalry in Caesar's army was especially powerful after Caesar recruiting competent riders and improving the weapons. Moreover, in the later period of the Roman empire, cavalry also plays an important role in patrolling the state's borders.

In cavalry usage in territorial expansion between Persian Empire and Roman Empire, they shared some similarities in using cavalry as a significant military force. For instance, they both used cavalry to protect infantry and the flank of armies because the moving speed of infantry is relatively slow, which makes their flank vulnerable to potential attack from the enemy. Thus cavalry plays an important role in protecting the flank of the armies depending on its high mobility. Additionally, the cavalry was used to collect intelligence of the energy armies and investigate the condition because of its exceptional flexibility and mobility. Furthermore, their use of cavalry both learned from other tribes. From an ideology perspective, they both realized the importance of the cavalry. So they actively aimed to learn cavalry techniques from others.

Despite those similarities, they have a number of differences when using cavalry. To specific, the Persian empire relied more heavily on its cavalry than the Roman empire since the Roman empire mainly used Phalanx that was composed of infantry, to be its most important part of the armies.

To sum up, in ancient times, the military success of an empire to a large extent owes to cavalry.

\section{CONCLUSION}

In summary, section I has first presented the historical development of the Persian empire regarding its territorial expansion. Then, section II has explained this phenomenon from the aspect of cavalry. After that, section III has compared this with the Chinese empire. Next, section IV has compared it with the Roman empire.

In conclusion, the essay deepens our understanding of the Persian empire. Moreover, the essay can be useful to reveal the historical root of contemporary disorder in the Middle East. Therefore, it might be helpful to propose solutions for the peace of the region.

The essay has several limitations. The analysis may be incomplete, and maybe there are other reasons. The single case provides limited explanations and may not fully explain other cases.

Future studies can focus on the economic and cultural perspective of the Persian empire. Also, future research can look into the expansion in other ancient empires.

\section{REFERENCES}

[1] Brooks, C. (2019, September 17). Persian Expansion. Retrieved April 6, 2021, from https://human.libretexts.org/@go/page/17016

[2] crystalinks, n.d. Achaemenid Empire. Retrieved from:https://www.crystalinks.com/Achaemenid_E mpire.htmlRobert

[3] Robert B. Strassler, book 7 Chapter 1-56: in The Histories, by Herodotus, FIRST ANCHOR BOOKS EDITION, 2009.

[4] Robert B. Strassler, book 9 Chapter 1-89: in The Histories, by Herodotus, FIRST ANCHOR BOOKS EDITION, 2009.

[5] Mandal, D., 2019. Introduction - Origins of the Achaemenid Persians. Retrieved from: https://www.realmofhistory.com/2019/11/05/10facts-achaemenid-persian-empire-army/

[6] Robert B. Strassler, book 1 Chapter 141-177: in The Histories, by Herodotus, FIRST ANCHOR BOOKS EDITION, 2009

[7] Guo J, Gu Dai Ya Zhou De Xun Ma, Cheng Ma Yu You Zhan Zu Qun, from "Zhong Guo She Hui Ke Xue" 2012(6)

[8] Chao Cuo, Han dynasty, "Yan Bing Shi Shu".

[9] UNVI, n.d. Roman Calvary (Equitatus) and Auxiliary. Retrieved from:https://www.unrv.com/military/romancavalry.php

[10] Bishop, M. C. (1988). Cavalry equipment of the Roman army in the first century AD. In Military equipment and the identity of Roman soldiers. Proceedings of the Fourth Roman Military Equipment Conference (pp. 67-195). British Archaeological Reports.

[11] Cartwright, M. (2014). Roman Cavalry. World History Encyclopedia. Retrieved from: https://www.worldhistory.org/Roman_Cavalry/ 